\title{
機能性複合材料としての元素ブロックならびに元素ブロック高分子 Element-blocks and Element-block Polymers as Functional Composite Materials
}

\author{
菅原 義之 \\ Yoshiyuki SUGAHARA \\ 早稲田大学 \\ Waseda University
}

元素ブロックは, 様々な元素からなる構造単位であり, 多 彩な元素の機能を活用することで高機能化できます．有機化 学的手法によって合成される無機骨格を有する元素ブロック は，新しい複合材料としての利用が期待できます。一方，無 機ナノ構造からの元素ブロックは，本協会の基礎技術である 無機ナノ構造の作製技術とその表面修飾技術によって作製さ れています。また，元素ブロックを連結することにより得ら れる元素ブロック高分子の高次構造制御による機能発現は, 高機能性複合材料の作製戦略として重要です。そこで，元素 ブロックと元素ブロック高分子についての成果を議論し，元 素ブロックの概念を活用して高機能性複合材料を発展させた いとの思いから, 本講演特集を企画・運営致しました。

本講演特集では, 合計で 11 件（特別講演 1 件, 招待講演 6 件 を含む)の講演が，3つのセッションに分けて行われました.

最初のセッションは，シロキサン多孔体を目指した大環状 シロキサン重合の検討，かご型有機シロキサンの合成とその 結晶化, かご型シルセスキオキサン構造を利用した元素ブ ロック高分子の合成, Ti-O-P 結合を有するかご型構造元素ブ
ロックの合成が取り上げられました。

2 番目のセッションでは, アゾベンゼン修飾シランの自己 組織化を用いた光応答材料の合成, ポリメチルメタクリレー ト修飾チタニアを導入したポリマーハイブリッドバルク体の 作製，液一液 2 層系を利用したリン酸エステル修飾チタニア を利用したポリマーハイブリッドの作製，有機修飾ジルコニ アナノ粒子を利用したポリマーハイブリッドの作製が取り上 げられました。 また, 中條京都大学教授による特別講演では, 元素ブロックと元素ブロック高分子のコンセプトを研究事例 とともにお示しいただきました.

3 番目のセッションでは, セリアナノ粒子と酸化鉄ナノ粒 子の作製，リキッドマーブルを利用した粉末状粘着剤の作製 が取り上げられました。

以上述べました通り，元素ブロックと元素ブロック高分子 に関する最新の素晴らしい研究成果を発表いただき，非常に 有意義な講演特集とすることができました。この紙面をお借 りして，研究成果を発表していただいた皆様と活発な討論に ご協力いただいた皆様に，心より御礼申し上げます. 